\title{
Investigation of Laboratory Parameters That Differentiate Complicated Appendicitis from Simple Appendicitis in Adults
}

\author{
Yetișkinlerde Komplike Apandisiti Basit Apandisitten Ayıran Laboratuvar Özelliklerinin \\ Araștırılması
}

(1) Özgür Dikme ${ }^{1}$, (1) Özlem Dikme²

${ }^{1}$ istanbul Training and Research Hospital, Clinic of Emergency, istanbul, Turkey

${ }^{2}$ Koç University Faculty of Medicine, Department of Emergency, İstanbul, Turkey

\begin{abstract}
Introduction: Acute appendicitis is one of the most common abdominal emergencies. In this study, we aimed to investigate preoperative laboratory parameters in patients with simple and complicated appendicitis.

Methods: The medical records of patients over 40 years of age with histopathologically diagnosed acute appendicitis between January and December 2015 were retrospectively reviewed. The patients were divided into two groups as simple and complicated. The relationship between appendicitis subgroups and laboratory parameters including white blood cell count, neutrophil count and percentage, lymphocyte count and percentage, basophil count and percentage, platelet count, mean platelet volume, plateletcrit, platelet distribution width was investigated. Neutrophil/lymphocyte ratio (NLR) and platelet/lymphocyte ratio (PLR) were also analyzed in these groups.

Results: A total of 156 patients were included in the study. Twenty-three patients (14.7\%) had simple appendicitis and the mean age of all patients was $50.5 \pm 8.5$ years. Male and elderly patients had more complicated appendicitis. In univariate analysis, percentage of neutrophils, lymphocyte count and percentage, lymphocyte count and percentage, basophil percentage, plateletcrit, NLR and PLR values were significantly different between the groups. However, in the multivariate logistic regression analysis comparing simple and complicated appendicitis data, only NLR value was found to be significant.

Conclusion: Neutrophil percentage, lymphocyte count and percentage, basophil percentage, plateletcrit and NLR were associated with complicated appendicitis in patients over 40 years of age, but only NLR was significant in multivariate analysis. However, these parameters can be used to distinguish complicated appendicitis at presentation.
\end{abstract}

Keywords: Acute appendicitis, adult, complicated appendicitis, laboratory

\section{öz}

Amaç: Akut apandisit en sık görülen abdominal acillerden birisidir. Bu çalışmada basit ve komplike apandisit hastalarında preoperatif laboratuvar değerlerini incelenmeyi amaçladık.

Yöntemler: Ocak-Aralık 2015 tarihleri arasında histopatolojik olarak akut apandisit tanısı konulmuş 40 yaș ve üzeri hastaların tıbbi kayıtları retrospektif olarak incelendi. Hastalar basit ve komplike olarak iki gruba ayrıldı. Beyaz kan hücresi sayımı, nötrofil sayısı ve yüzdesi, lenfosit sayısı ve yüzdesi, bazofil sayısı ve yüzdesi, trombosit sayısı, ortalama trombosit hacmi, plateletkrit, trombosit dağılım genişliği ve apandisit alt grupları arasındaki ilişki araştıııldı. Aynı zamanda nötrofil/ lenfosit oranı (NLR) ve trombosit/lenfosit oranı (PLR) da bu gruplarda analiz edildi.

Bulgular: Kırk yaş üzeri 156 hasta çalıșmaya dahil edildi. Hastaların 23'ü $(\% 14,7)$ basit apandisitti ve tüm hastaların yaş ortalaması $50,5 \pm 8,5$ yıl olarak saptandı. Erkek ve yaşlı hastalarda daha fazla komplike apandisit saptandı. Tek değișkenli analizde nötrofil yüzdesi, lenfosit sayı ve yüzdesi, lenfosit sayısı ve yüzdesi, bazofil yüzdesi, plateletkrit, NLR ve PLR değerleri gruplar arasında anlamlı farklı bulundu. Basit ve komplike apandisit verilerinin karşılaştırıldığı çok değișkenli lojistik regresyon analizinde sadece NLR değeri anlamlı bulundu.

Sonuç: Kırk yaş üstü hastalarda nötrofil yüzdesi, lenfosit sayısı ve yüzdesi, bazofil yüzdesi, plateletkrit ve NLR'nin komplike apandisit ile ilişkili olduğu ancak sadece NLR'nin çok değişkenli analizde anlamlı olduğu saptandı. Buna rağmen bu parametreler başvuruda komplike apandisitin ayırt edilmesinde kullanılabilir.

Anahtar Kelimeler: Akut apandisit, yetişkin, komplike apandisit, laboratuvar 


\section{Introduction}

The lifetime risk of acute appendicitis is approximately $8 \%$, and although it is one of the most common abdominal emergencies, its pathogenesis is still poorly understood. It is thought to be a multifactorial clinical picture caused by mechanical, infectious and genetic processes leading to appendix inflammation (1). Appendicitis can be seen as simple or uncomplicated (inflammation of the appendix with or without phlegmonous changes in surrounding tissues) or complicated appendicitis (inflammation of the appendix causing gangrene or perforation with or without abscess formation). Perforation may occur in $13-20 \%$ of patients presenting with acute appendicitis (2). Although it has long been assumed that simple appendicitis will eventually lead to a complicated form, recent data raise doubts that different forms of biological appendicitis may exist. Although general appendicitis rates decrease, the rate of patients presenting with perforated appendicitis or after the onset of symptoms does not decrease (3). Acute complicated appendicitis causes serious problems such as wound infection, intraabdominal abscess formation, postoperative intestinal obstruction, prolongation of recovery and hospital stay and increased cost. In addition, whether appendicitis is complicated or not has an important role in determining the treatment method to be selected. Therefore, early recognition of complicated appendicitis cases is critical by making a distinction between complicated and simple appendicitis. Although many studies have been published regarding the prediction of complicated appendicitis, there is no definite method to differentiate preoperative complicated appendicitis from simple appendicitis (4-6).

In this study, we aimed to investigate the preoperative laboratory characteristics of simple and complicated appendicitis in patients over 40 years of age diagnosed with acute appendicitis histopathologically.

\section{Methods}

This study was performed retrospectively on the medical records of the patients who were diagnosed as acute abdomen and underwent appendectomy (open and laparoscopic) between 01.01.2015-31.12.2015 in the Emergency Medicine Clinic of İstanbul Training and Research Hospital, University of Health Sciences. The study was started after the approval of the hospital istanbul Training and Research Hospital Ethics Committee (decision no: 759).

All patients who underwent appendectomy for acute appendicitis were included in the study. Of these patients, patients with no histopathological appendicitis, patients under 41 years of age, patients with missing data, and patients who underwent incidental appendectomy during surgery for any other reason were excluded from the study.

Demographic characteristics of all patients, initial vital signs recorded on admission, laboratory values including leucocyte, neutrophil count, neutrophil percentage, lymphocyte count, platelet count, mean platelet volume (MPV), plateletcrit and platelet distribution width (PDW) values were recorded. Neutrophil/lymphocyte ratio (NLR) was calculated by dividing the neutrophil count by lymphocyte count, and platelet/ lymphocyte ratio (PLR) was calculated by dividing the platelet count by lymphocyte count.

The operation records and histopathology reports were examined, and the widest and longest dimensions of the excised appendix material were noted. Infiltration of muscularis propria with polymorphonuclear cells was accepted as histological acute appendicitis.

All patients included in the study were divided into two groups as simple and complicated appendicitis. Patients with perforated or gangrenous appendix or patients with periappendiceal abscess were included in the complicated appendicitis group. Patients with histopathological findings consistent with perforation or gangrene from patients who were included in the simple appendicitis group by intraoperative evaluation were also included in the complicated appendicitis group. Patients without intraoperative and histopathological perforation or gangrenous features, and patients without periappendiceal abscess formed simple appendicitis group.

\section{Statistical Analysis}

Statistical analysis was performed using SPSS 15.0 (SPSS Inc. Chicago, IL, USA). The normality of continuous variables was evaluated by Kolmogorov Smirnov test. Continuous variables were expressed as mean \pm standard deviation, and categorical variables were expressed as number and percentage. Chi-square test was used for comparisons between categorical variables. Student's t-test was used for comparison of the normally distributed parameters and Mann-Whitney $U$ test was used for the comparison of non-normally distributed parameters. The effect level was investigated by univariate and multivariate logistic regression. Sensitivity, specificity and odds ratios were calculated for the factors that differentiated between simple and complicated appendicitis groups. All analyzes were performed at 95\% confidence interval. Statistical significance was accepted as $p<0.05$.

\section{Results}

The records of 550 patients who underwent appendectomy during the one-year period were reached. Three hundred and eighty-two patients (69.5\%) were excluded because they were 40 years or younger Histopathology reports of the remaining 168 patients revealed normal appendicitis in 12 (7.1\%) patients. In conclusion, this study was carried out with 156 patients who underwent appendectomy for acute appendicitis. In the operation notes and histopathological examination of 133 patients (85.3\%), no pathology could be detected for inclusion to the complicated group. The remaining 23 patients (14.7\%) had pathological findings of complicated appendicitis in at least one of the operation notes or histopathological examinations.

The mean age of the patients was $50.5 \pm 8.5$ years (range: $41-79$ years). The mean age of the patients in the complicated appendicitis group ( $56.3 \pm 10.9$ years) was higher than the mean age of the patients in the simple appendicitis group ( $49.5 \pm 7.7$ years) $(p=0.004)$. Seventy-nine patients (50.6\%) included in the study were male. The incidence of complicated appendicitis was higher in male patients than in female patients ( $21.5 \%$ vs $7.8 \%$, respectively, $p=0.016)$. All laboratory values of simple and complicated appendicitis cases are shown in Table 1. The relationship between increased NLR and increased risk of complicated appendicitis is shown in Figure 1.

When univariate logistic regression analysis was performed, age, gender, lymphocyte count, percentage of neutrophils, percentage of 
Table 1. Comparison of simple and complicated groups according to the characteristics of the patients included in the study

\begin{tabular}{|c|c|c|c|c|c|}
\hline \multirow{2}{*}{ Variable } & \multicolumn{2}{|l|}{ All patients } & \multirow{2}{*}{$\begin{array}{l}\text { Simple appendicitis } \\
\text { Mean } \pm \text { SD }\end{array}$} & \multirow{2}{*}{$\begin{array}{l}\text { Complicated appendicitis } \\
\text { Mean } \pm \text { SD }\end{array}$} & \multirow{2}{*}{ p } \\
\hline & Mean \pm SD & Min-Max & & & \\
\hline Length of appendix $(\mathrm{cm})$ & $6.5 \pm 1.6$ & $3.0-13.0$ & $6.5 \pm 1.7$ & $6.7 \pm 1.5$ & 0.538 \\
\hline Width of appendix (cm) & $1.0 \pm 0.7$ & $0.3-8.0$ & $1.0 \pm 0.7$ & $1.2 \pm 0.5$ & 0.002 \\
\hline Leukocyte count (109/L) & $13.1 \pm 4.5$ & $1.0-30.1$ & $12.9 \pm 4.3$ & $14.2 \pm 5.4$ & 0.245 \\
\hline Platelet count (109/L) & $249.8 \pm 62.8$ & $82.0-538.0$ & $252.7 \pm 61.4$ & $233.0 \pm 69.3$ & 0.165 \\
\hline Neutrophil count (109/L) & $10.3 \pm 4.3$ & $0.2-28.7$ & $10.1 \pm 4.2$ & $12.0 \pm 5.0$ & 0.092 \\
\hline Lymphocyte count (109/L) & $1.9 \pm 0.9$ & $0.2-4.7$ & $2.0 \pm 0.8$ & $1.4 \pm 1.0$ & 0.003 \\
\hline Neutrophil percentage (\%) & $76.9 \pm 11.7$ & $20.0-96.4$ & $75.6 \pm 11.8$ & $84.2 \pm 7.7$ & $<0.001$ \\
\hline Lymphocyte percentage (\%) & $16.8 \pm 10.0$ & $2.0-65.2$ & $17.9 \pm 10.2$ & $10.2 \pm 6.1$ & $<0.001$ \\
\hline MPV (fL) & $9.9 \pm 1.0$ & $7.0-12.5$ & $10.0 \pm 1.0$ & $9.6 \pm 0.9$ & 0.100 \\
\hline Plateletcrit (\%) & $0.2 \pm 0.1$ & $0.1-0.6$ & $0.3 \pm 0.1$ & $0.2 \pm 0.1$ & 0.025 \\
\hline PDW (\%) & $16.2 \pm 0.9$ & $14.9-26.5$ & $16.2 \pm 1.0$ & $16.1 \pm 0.4$ & 0.498 \\
\hline Urea (mg/dL) & $29.6 \pm 11.1$ & $14.9-85.2$ & $28.5 \pm 9.6$ & $36.2 \pm 16.3$ & 0.035 \\
\hline Creatinine $(\mathrm{mg} / \mathrm{dL})$ & $0.8 \pm 0.2$ & $0.3-1.9$ & $0.8 \pm 0.2$ & $1.0 \pm 0.4$ & 0.001 \\
\hline Glucose (mg/dL) & $118.8 \pm 34.4$ & $78.0-330.0$ & $118.6 \pm 36.4$ & $119.8 \pm 21.7$ & 0.232 \\
\hline NLR & $7.3 \pm 6.9$ & $0.3-46.9$ & $6.4 \pm 5.9$ & $12.5 \pm 9.7$ & $<0.001$ \\
\hline PLR & $166.8 \pm 126.4$ & $48.3-936.4$ & $151.3 \pm 89.7$ & $256.0 \pm 233.4$ & 0.005 \\
\hline
\end{tabular}

MPV: mean platelet volume, SD: standard deviation, Min: minimum, Max: maximum, fL: femtoliter, PDW: platelet distribution width, NLR: neutrophil/lymphocyte ratio, PLR: platelet/ lymphocyte ratio

Table 2. Logistic regression analysis

\begin{tabular}{|c|c|c|c|c|c|c|c|c|c|c|}
\hline \multirow{3}{*}{$\begin{array}{l}\text { Variable } \\
\text { Age }\end{array}$} & \multicolumn{5}{|c|}{ Univariate model } & \multicolumn{5}{|c|}{ Multivariate model } \\
\hline & \multirow{2}{*}{$\begin{array}{l}\mathbf{O R} \\
1.09\end{array}$} & \multicolumn{3}{|c|}{$95 \% \mathrm{Cl}$} & \multirow{2}{*}{$\begin{array}{l}\mathbf{p} \\
0.001\end{array}$} & \multirow{2}{*}{$\begin{array}{l}\mathbf{O R} \\
1.09\end{array}$} & \multicolumn{3}{|c|}{$95 \% \mathrm{Cl}$} & \multirow{2}{*}{$\begin{array}{l}\mathbf{p} \\
0.002\end{array}$} \\
\hline & & 1.03 & - & 1.14 & & & 1.03 & - & 1.15 & \\
\hline Gender & 3.24 & 1.20 & - & 8.74 & 0.020 & 3.54 & 1.18 & - & 10.60 & 0.024 \\
\hline Lymphocyte count & 0.41 & 0.23 & - & 0.75 & 0.003 & & & & & \\
\hline Neutrophil percentage & 1.11 & 1.04 & - & 1.18 & 0.001 & & & & & \\
\hline Lymphocyte percentage & 0.87 & 0.80 & - & 0.94 & 0.001 & & & & & \\
\hline PCT & 0.00 & 0.00 & - & 0.35 & 0.028 & & & & & \\
\hline Urea & 1.05 & 1.02 & - & 1.09 & 0.005 & & & & & \\
\hline Creatinine & 14.39 & 2.66 & - & 77.76 & 0.002 & & & & & \\
\hline NLR & 1.10 & 1.04 & - & 1.17 & 0.002 & 1.09 & 1.03 & - & 1.15 & 0.005 \\
\hline PLR & 1.00 & 1.00 & - & 1.01 & 0.004 & & & & & \\
\hline
\end{tabular}

PCT: plateletcrit, NLR: neutrophil/lymphocyte ratio, PLR: platelet/lymphocyte ratio, OR: odds ratio, Cl: confidence interval

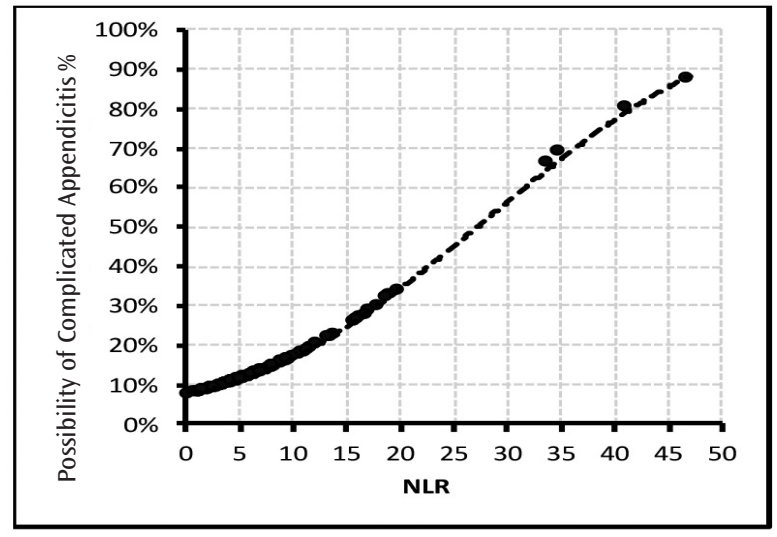

Figure 1. Risk graph of NLR increase and possibility of complicated appendicitis

NLR: neutrophil/lymphocyte ratio lymphocytes, percentage of basophils, plateletcrit (PCT), urea, creatinine, NLR, PLR values were observed to differentiate complicated and simple appendicitis. In the multivariate logistic regression, significant and independent efficacy of age, gender, and NLR was found to differentiate simple and complicated appendicitis (Table 2).

\section{Discussion}

Acute appendicitis is the most common surgical cause of acute abdomen affecting all age groups. Complicated acute appendicitis is a serious problem with prolonged recovery and length of hospital stay and increased cost, which adversely affect clinical outcome and treatment outcomes. Being simple or complicated is important in determining the treatment method to be selected in appendicitis. In this study, preoperative laboratory values of adult acute appendicitis patients were investigated and the role of these values in differentiating complicated and simple appendicitis was demonstrated. Age, gender, lymphocyte 
count and percentage, percentage of neutrophils, percentage of basophils, PCT, urea, creatinine, NLR, PLR and appendix diameter were found to be associated with complicated appendicitis.

In this study, we found significant differences between the groups in terms of demographic characteristics such as age and gender. The mean age of the patients in the complicated appendicitis group was higher than the patients in the simple appendicitis group. There are similar reports in the literature (7). This can be explained by the fact that acute appendicitis occurs more frequently with atypical symptoms in elderly patients and the diagnosis is more difficult than in younger patients. Similarly, in accordance with the literature, we found that complicated appendicitis was more common in male patients.

There are many reports in the literature regarding the association of complete blood count parameters with underlying inflammatory or infectious pathologies. Leukocyte elevation is quite common in the diagnosis of acute appendicitis, but it is a non-diagnostic condition. Yang et al. (8) reported that the increase in the percentage of leukocytes and neutrophils correlated with the degree of appendiceal inflammation. Paragiotopoulou et al. (9) reported that leukocyte count might be used in the diagnosis of appendicitis but that it was not suitable for differential diagnosis of perforated acute appendicitis. In our study, leukocyte and neutrophil counts were not significantly different but the percentage of neutrophils was significantly higher in complicated acute appendicitis cases. The physiological leukocyte response due to triggering factors causes an increase in neutrophil count and a decrease in lymphocyte count. NLR, which is calculated by the ratio of these two parameters to each other, is used as an inflammatory parameter reflecting this physiological response $(10,11)$. Kahramanca et al. (12) reported that NLR is a parameter that can be used both in the diagnosis of appendicitis and in the differential diagnosis of complicated and non-complicated appendicitis. Similarly, in our study, NLR was significantly higher in patients with complicated acute appendicitis.

There are reports in the literature that express the relationship between platelet activation and pathophysiological process in inflammatory diseases. Assuming that platelet size is associated with activity and functionality, the assumption is that larger platelets are younger and more reactive. It is reported that PLR, calculated by the ratio of platelet count to lymphocyte count, can help predict complicated appendicitis (13). Similarly, in our study, PLR value was found to be significantly higher in patients with complicated appendicitis. MPV is the MPV in the blood and is calculated by dividing the PCT value by the platelet count. There are conflicting publications on the change of MPV in acute appendicitis. While some publications report a decrease in acute appendicitis (14), some reports report an increase (15). There are also reports in the literature stating that there is no relationship between MPV and acute appendicitis (16). In our study, we did not find any significant difference between MPV values in simple and complicated acute appendicitis groups. We thought that this might be due effects of other inflammatory causes on MPV that we could not detect. Aydogan et al. (17) reported that PDW values were significantly higher in perforated acute appendicitis cases. In another study, Fan et al. (16) reported an increase in PDW in patients with acute gangrenous appendicitis when compared with healthy control group. However, there are also studies reporting no significant difference in PDW values in complicated acute appendicitis (14). Similarly, in our study, we did not find any significant difference in PDW value between simple and complicated acute appendicitis groups.

Tanrikulu et al. (18) reported that appendiceal wall thickness, diameter and length were risk factors for perforation in their measurements of excised surgical material in patients with acute appendicitis. In our study, we did not find any relationship between length and complicated appendicitis. However, there was a positive correlation between appendix diameter and complicated appendicitis.

There were some limitations in our study. First of all, our study is a single-center study, so it is not sufficient to apply the results to the general population. Evaluations were made according to the results of a single laboratory. Therefore, no comment can be made about changes after follow-up or treatment. In addition, no additional research has been conducted on the presence of hematological malignancy.

\section{Conclusion}

In this study, age, gender, lymphocyte count and percentage, neutrophil percentage, basophil percentage, PCT, urea, creatinine, NLR and PLR values were significantly different between simple and complicated appendicitis patients, but multivariate analysis showed that only age, gender and NLR were significant and independent factors in differentiating complicated appendicitis.

Ethics Committee Approval: The study was started after the approval of the hospital İstanbul Training and Research Hospital Ethics Committee (decision no: 759).

Informed Consent: Retrospective study.

Peer-review: Externally peer-reviewed.

Author Contributions: Concept - Özlem D., Ö.D.; Design - Özlem D., Ö.D.; Data Collection and/or Processing - Özlem D., Ö.D.; Analysis and/ or Interpretation - Özlem D., Ö.D.; Literature Search - Özlem D., Ö.D.; Writing Manuscript - Özlem D., Ö.D.

Conflict of Interest: No conflict of interest was declared by the authors.

Financial Disclosure: The authors declared that this study received no financial support.

\section{References}

1. Bhangu A, Søreide K, Di Saverio S, Assarsson JH, Drake FT. Acute appendicitis: modern understanding of pathogenesis, diagnosis, and management. Lancet 2015; 386: 1278-87.

2. Andersson RE, Hugander A, Thulin AJ. Diagnostic accuracy and perforation rate in appendicitis: association with age and sex of the patient and with appendicectomy rate. Eur J Surg 1992; 158: 37-41.

3. Livingston EH, Woodward WA, Sarosi GA, Haley RW. Disconnect between incidence of nonperforated and perforated appendicitis: implications for pathophysiology and management. Ann Surg 2007; 245: 886-92.

4. Kim TH, Cho BS, Jung JH, Lee MS, Jang JH, Kim CN. Predictive factors to distinguish between patients with noncomplicated appendicitis and those with complicated appendicitis. Ann Coloproctol 2015; 31: 192-7.

5. Adams HL, Jaunoo SS. Hyperbilirubinaemia in appendicitis: the diagnostic value for prediction of appendicitis and appendiceal perforation. Eur J Trauma Emerg Surg 2016; 42: 249-52. 
6. Atema J], van Rossem CC, Leeuwenburgh MM, Stoker J, Boermeester MA. Scoring system to distinguish uncomplicated from complicated acute appendicitis. Br J Surg 2015; 102: 979-90.

7. Ishizuka M, Shimizu T, Kubota K. Neutrophil-to-lymphocyte ratio has a close association with gangrenous appendicitis in patients undergoing appendectomy. Int Surg 2012; 97: 299-304.

8. Yang HR, Wang YC, Chung PK, Chen WK, Jeng LB, Chen RJ. Laboratory tests in patients with acute appendicitis. ANZ J Surg 2006; 76: 71-4.

9. Paragiotopoulou IG, Parashar D, Lin R, Antonowicz S, Wells AD, Bojura FM, et al. The diagnostic value of white cell count, C-reactive protein and bilirubin in acute appendicitis and its complications. Ann R Coll Surg Engl 2013; 95: 21521

10. Bröker ME, van Lieshout EM, van der Elst M, Stassen LP, Schepers T. Discriminating between simple and perforated appendicitis. J Surg Res 2012; 176: 79-83.

11. Jung SK, Rhee DY, Lee WJ, Woo SH, Seol SH, Kim DH, et al. Neutrophil-tolymphocyte count ratio is associated with perforated appendicitis in elderly patients of emergency department. Aging Clin Exp Res 2017; 29: 529-36.

12. Kahramanca S, Ozgehan G, Seker D, Gökce El, Seker G, Tunç G, et al. Neutrophilto-lymphocyte ratio as a predictor of acute appendicitis. Ulus Travma Acil Cerrahi Derg 2014; 20: 19-22.
13. Kahramanca S, Ozgehan G, Kaya O, Gökce IE, Kucukpınar TH, KargıCı H. Platelet to Lymphocyte Ratio and Acute Appendicitis. Kafkas J Med Sci 2017; 7: 153-7.

14. Ceylan B, Aslan T, Cinar A, Ruhkar Kurt A, Akkoyunlu Y. Can platelet indices be used as predictors of complication in subjects with appendicitis? Wien Klin Wochenschr 2016; 128: 620-5.

15. Aktimur R, Cetinkunar S, Yildirim K, Ozdas S, Aktimur SH, Gokakin AK. Mean platelet volume is a significant biomarker in the differential diagnosis of acute appendicitis. Inf Cell Sig 2015; 2: 930

16. Fan Z, Pan J, Zhang Y, Wang Z, Zhu M, Yang B, et al. Mean platelet volume and platelet distribution width as markers in the diagnosis of acute gangrenous appendicitis. Dis Markers 2015; 2015: 542013.

17. Aydogan A, Akkucuk S, Arica S, Motor S, Karakus A, Ozkan OV, et al. The analysis of mean platelet volume and platelet distribution width levels in appendicitis. Indian J Surg 2015; 77: 495-500.

18. Tanrıkulu Y, Yılmaz G, Şen Tanrıkulu C, Temi V, Köktürk F, Çăgsar M, et al. A prospective clinical study of the effects of the physical features of the appendix on perforation. Ulus Travma Acil Cerrahi Derg 2015; 21: 440-5. 